\author{
Dariusz Sokołowski \\ Nicolaus Copernicus University in Torun \\ Department of Spatial Management and Tourism \\ sokol@umk.pl
}

\title{
DEVELOPMENT OF TOURISM IN A COASTAL GMINA IN TERMS OF OBJECTIVE DATA AND THE INHABITANTS' OPINIONS: THE EXAMPLE OF THE GMINA OF KROKOWA
}

\begin{abstract}
Tourism is often seen as an important factor in local development. The good or relatively good financial standing of tourist gminas and their inhabitants is usually emphasised while the positive impact of tourism on the development of infrastructure and other effects generally seen as favourable. What is less often emphasised are the problems associated with the development of tourism. The purpose of this article is to recognise the consequences of tourism development in a gmina of high tourism and recreation value and set them against the opinions of its inhabitants.
\end{abstract}

Keywords: tourism, local development, coastal areas.

\section{INTRODUCTION}

The role of tourism in local development is often overestimated. Numerous studies prepared on request of local government treat tourism as a way to reduce unemployment, a source of income for the population and budget, a stimulus to infrastructural development, a way to obtain external financing sources, etc. Is such optimism supported in the Polish context? Discussion of this view is the main objective of this article.

A rural gmina was selected as a case study due to its special prerequisites for the development of leisure tourism and the high number of tourists. It was assumed that in this type of administrative unit it will be easy to confirm the benefits of developing a specific function. It will also be possible to show whether the positive role of tourism is overestimated and if its negative consequences are also visible. Research in the Gmina of Krokowa, which occupies the western part of the Poviat of Puck in the Pomorskie Voivodeship, was based on (comparative) data from the Central Statistical Office (GUS), the Krokowa Gmina Offices, the Poviat Labour Office (PUP) in Puck, and questionnaire surveys conducted among gmina inhabitants ${ }^{1}$. The main objective of the questionnaire was to set the objective data (statistics) against the perception of tourism by the local community.
The development of a specific type of economic function is usually associated with complex interactions and consequences, both positive and negative. In the case of tourism one can observe its impact on economic, spatial and social spheres. If the impact of a particular function on the environment is strong enough, and it can manifest itself too in its impact on the conditions and quality of life of residents. The limited space of this paper does not allow for a detailed examination of these issues, and therefore some will be presented simply to provide an overview.

\section{IMPACT OF TOURISM ON THE DEVELOPMENT OF THE GMINA OF KROKOWA}

\subsection{ECONOMIC AND FINANCIAL EFFECTS}

The impact of tourism on the local economy is usually multi-dimensional. First of all, tourism stimulates the local markets in accommodation, catering, shopping, transportation, along with cultural and entertainment services, thus creating new jobs, as well as providing a source of budget revenue and household income in 
tourism resorts (cf. GOŁEMBSKI 2002, CZERWIŃSKI 2006). The consequence of tourism development is the reduction in importance of other activities, in particular agriculture, observed both in the transformation of the employment structure, as well as changes in land use (a significant portion of agricultural land has been used for housing, services and infrastructure). What is also worth noting is the decreasing importance of fishing which in the past played a significant role in some coastal towns and villages.

A manifestation of economic activity in the gmina is the number of registered businesses in its territory (Fig. 1). From the beginning of the transformation it has been growing rapidly (from 271 in 1995 to 970 in 2012), but with some fluctuations in 2001-07. In 2012, the ratio of registered businesses reached 915 per 10000 inhabitants and is higher than for rural areas in the Pomorskie Voivodeship (794) and for rural areas in Poland in general (686).

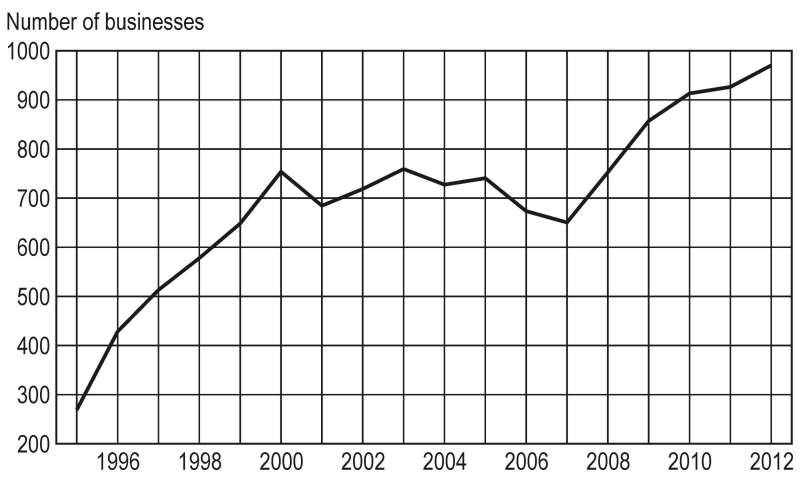

Fig. 1. Changes in the number of businesses in the Gmina of Krokowa

Source: compiled by the author on the basis of the GUS data

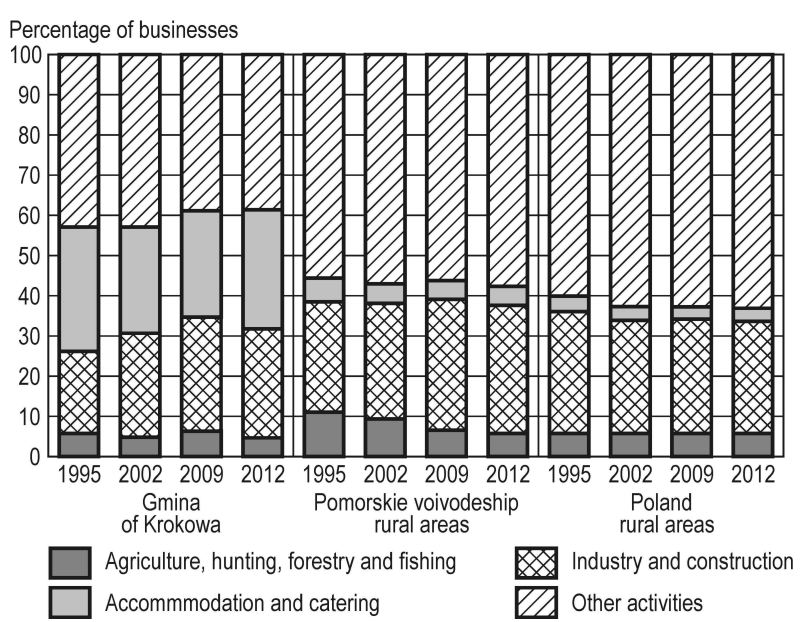

Fig. 2. Changes in the business structure in the Gmina of Krokowa relative to comparative areas Source: compiled by the author on the basis of GUS data

The registered business structure clearly shows the important role of tourism in the gmina (Fig. 2). The proportion of businesses included in Section I (accommodation and catering) of the 'Polish Classification of Activities' (PKD 2007) is about $30 \%$ of the total $(31.0 \%$ in $1995,26.8 \%$ in $2002,26.3 \%$ in $2009,29.8 \%$ in 2012 ).

According to the Krokowa Gmina Offices, 361 businesses (43.4\%) are registered in Section I, of which 276 operate in the field of accommodation and 85 in catering services (November 2012). The corresponding changes are illustrated in Figure 3.

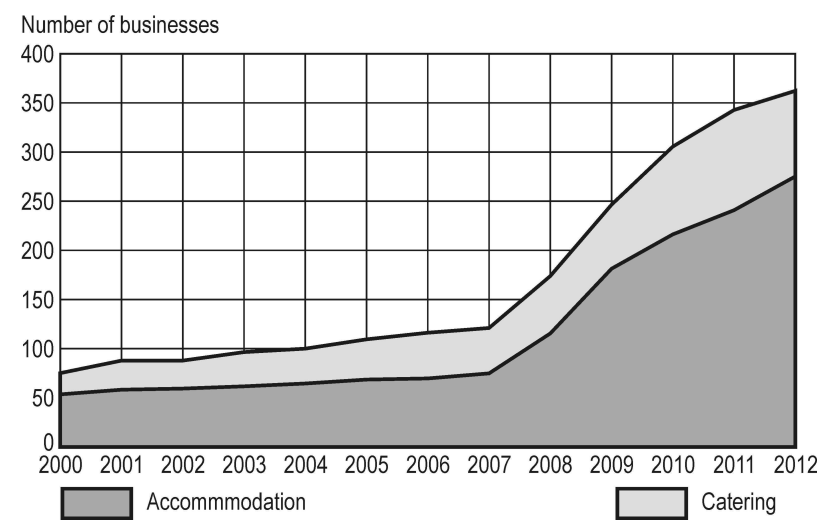

Fig. 3. Changes in the number of business entities registered in the Section I (PKD 2007) in the Gmina of Krokowa Source: compiled by the author on the basis of data from the Krokowa Gmina Offices

Activities related to tourism generate revenue for the gmina budget mainly from taxes on corporations and individuals, as well as local taxes. European Union grants are an important component of budget revenue whose aims include the development of tourism.

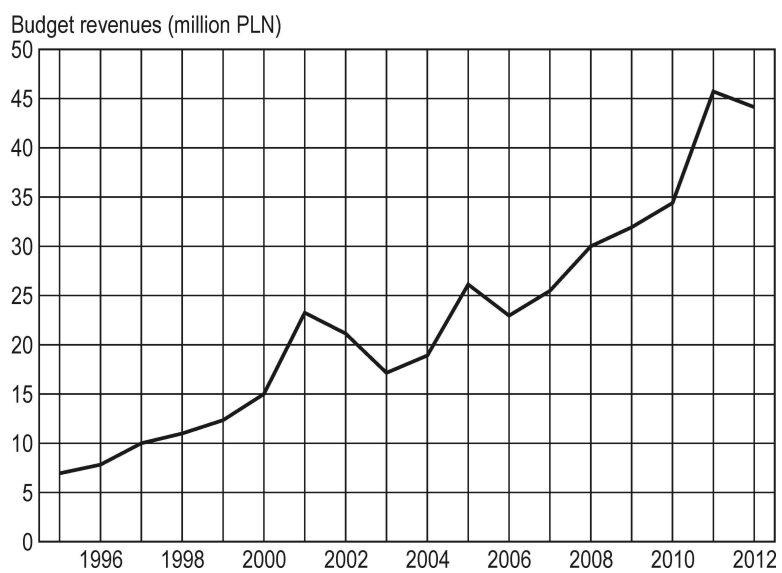

Fig. 4. Changes in the budget revenues of the Gmina of Krokowa (million PLN)

Source: compiled by the author on the basis of GUS data

The growth of budget revenue for the Gmina of Krokowa is high (Fig. 4). In 1995-2012 it reached an average of $11.6 \%$ annually, but this is similar to the national $(11.1 \%)$ and voivodeship $(12.7 \%)^{2}$ levels. It is 
difficult to demonstrate total budget revenue related to tourism as some of them are 'hidden' in various taxes and fees. Direct revenue from the local tax has increased in recent years by about 100\% (115000 PLN in 2007, 242000 in 2011, about 210000 in 2009, 2010, 2012), but this is only $0.5 \%$ of the gmina budget. Some idea of the scale of the stimulating impact of tourism can be shown by a comparison of the size of the budget per inhabitant to corresponding figures for Poland, voivodeship and poviat, against the background of which the Gmina of Krokowa looks favourable (Fig. 5).

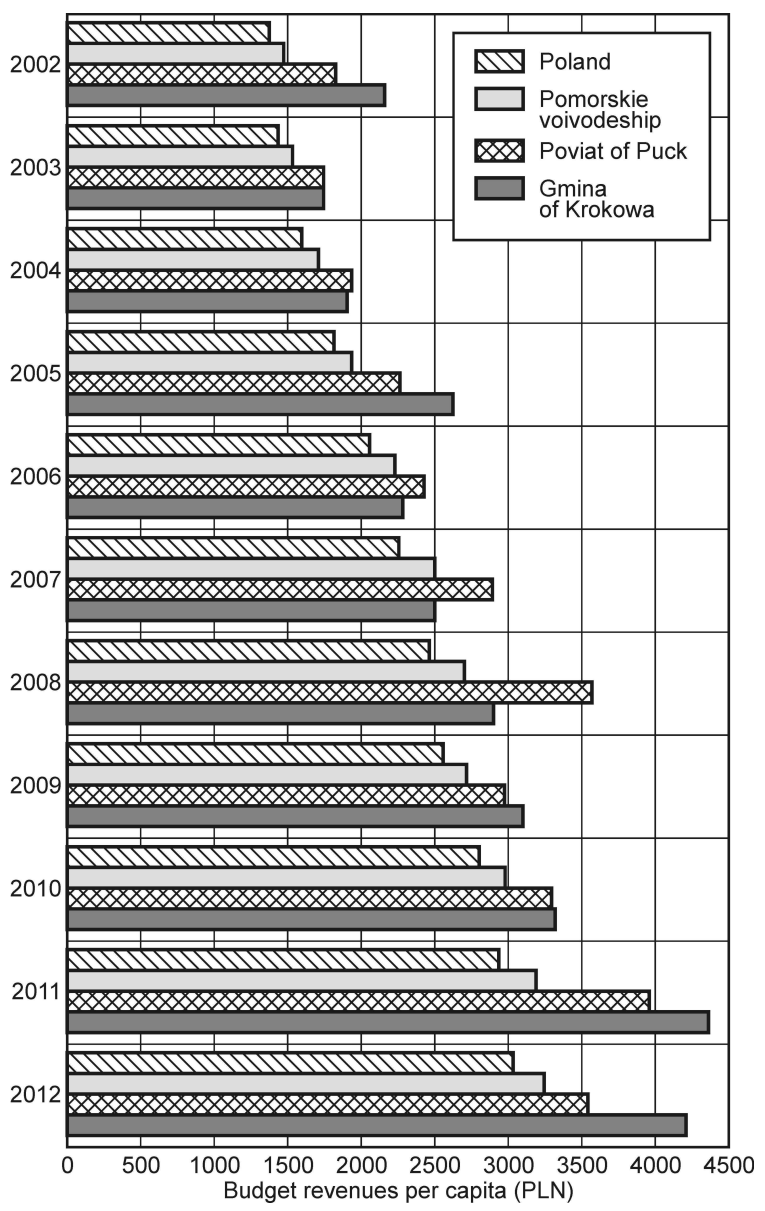

Fig. 5. Changes in budget revenue for the Gmina of Krokowa per capita (PLN) against comparative areas (excluding towns with poviat rights)

Source: compiled by the author on the basis of GUS data

\subsection{IMPACT ON THE LABOUR MARKET}

The above-average entrepreneurship of gmina residents and favourable development conditions affect the level of unemployment. Their number has undergone significant long-term as well as seasonal changes. In 2000-12 it ranged (as of the end of the year) from 855 to 267 and seasonal fluctuations are illustrated in Table 1. In most years (2010-12) unemployment de- creased during the summer by about 100 compared to winter months ${ }^{3}$. This is due to the increased demand for seasonal work, mainly in hotels, catering and trade.

Table 1. Unemployed in the Gmina of Krokowa by months

\begin{tabular}{|l|c|c|c|c|}
\hline \multirow{2}{*}{ Month } & \multicolumn{4}{|c|}{ Year } \\
\cline { 2 - 5 } & 2009 & 2010 & 2011 & 2012 \\
\hline January & 324 & 455 & 481 & 514 \\
\hline February & 349 & 491 & 489 & 532 \\
\hline March & 367 & 479 & 477 & 527 \\
\hline April & 361 & 477 & 427 & 490 \\
\hline May & 359 & 423 & 397 & 457 \\
\hline June & 354 & 387 & 362 & 431 \\
\hline July & 345 & 338 & 322 & 407 \\
\hline August & 345 & 337 & 337 & 403 \\
\hline September & 385 & 394 & 387 & 444 \\
\hline October & 377 & 410 & 408 & 428 \\
\hline November & 393 & 425 & 416 & 444 \\
\hline December & 413 & 448 & 455 & 494 \\
\hline
\end{tabular}

Source: data from the Poviat Labour Office in Puck.

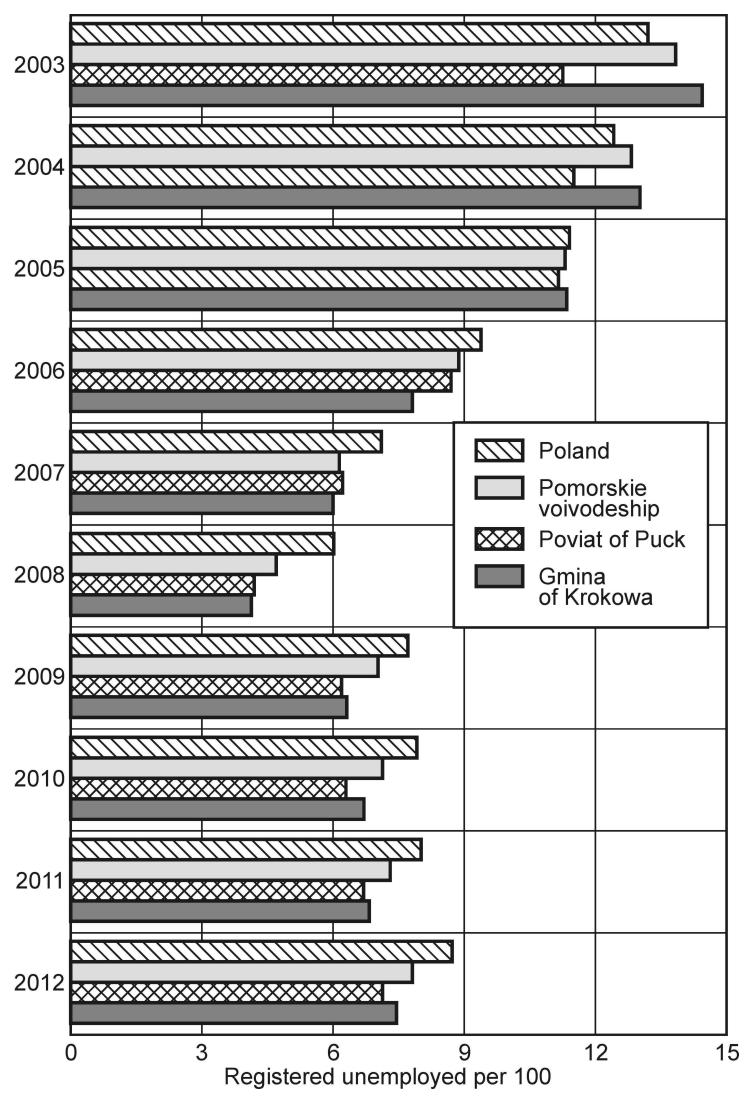

Fig. 6. Registered unemployed per 100 (at age of productivity) in the Gmina of Krokowa against comparable areas Source: compiled by the author on the basis of GUS data

Changes in unemployment in compared administrative units are clearly correlated with each other (similar trends) however, a relative improvement can be observed in the Gmina of Krokowa since 2006 when unemployment was lower than both the country as a whole and the voivodeship (Fig. 6). 


\subsection{SPATIAL EFFECTS (INFRASTRUCTURE, TOURISM FACILITIES, ARCHITECTURE)}

Spatial transformation under the influence of tourism is not only manifested in land use change, but also through the development of infrastructure. This contributes to the development of various sectors of the economy and an improvement in living conditions and quality of life for all gmina residents (cf. RÓŻYCKI 2006).

Funds for infrastructure investments come from the gmina's own funds and various grants, mainly from the European Union. According to the Krokowa Gmina Offices, at the end of 2012 the total subsidy from the EU was almost 45 million PLN, which puts the Gmina of Krokowa in fourth place out of 81 rural gminas in the Pomorskie Voivodeship. The total sum of the grants in 2010-12 was 21.7 million PLN. Most of these funds were spent on the construction of the sewage system $(45.8 \%)$ and investment in education (12.3\%). The share spent on tourism (fully or partly) was also significant (Fig. 7). The following investments should be mentioned: the construction of a bicycle path between Swarzewo and of Krokowa $(6.0 \%$ of the grant), the construction of four marinas on Lake Żarnowieckie $(12.4 \%)$ and an access road (locally called the 'promenade'), together with accompanying infrastructure, to the fishing port and the planned port service facility in Dębki (10.2\%).
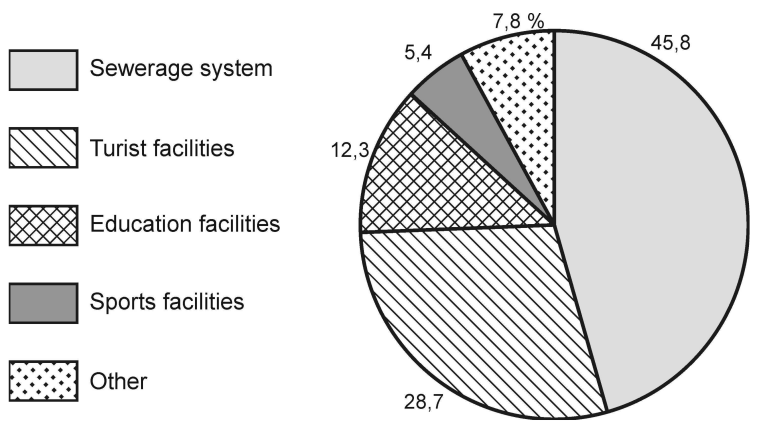

Fig. 7. Structure of EU subsidised investment in the Gmina of Krokowa: 2010-12

Source: compiled by the author based on data from the Krokowa Gmina Offices

In recent years there has been rapid increase in the 'tourism base' in the Gmina of Krokowa, including accommodation. In the period 2004-12 the number of places of accommodation ${ }^{4}$ (hotels or other) increased (according to GUS data) from 17 to 59, i.e. 3.5-fold, while nationally it was an increase by $36 \%$, and in the Pomorskie Voivodeship by 59\%. The number of beds in the gmina (with considerable annual fluctuations) by 85\% (from 1026 to 1900), while nationally and in the Pomorskie Voivodeship the growth was $16 \%$ and $6 \%$, respectively. The number of overnight stays increased in the gmina by $69 \%$, while nationally and in the Voivodeship by about $33 \%$ and $24 \%$.

The development of the technical infrastructure and tourism facilities has been accompanied by another spatial manifestation of the impact of tourism - changes in building - which in particular has transformed the landscape. Scattered single-family housing has been consolidated and converted to buildings serving tourist functions. Not only the number but also the volume of buildings has increased; in seaside settlements three- or four-storey buildings dominate. The growth of construction in the Gmina of Krokowa is one of the highest in Poland (Fig. 8).

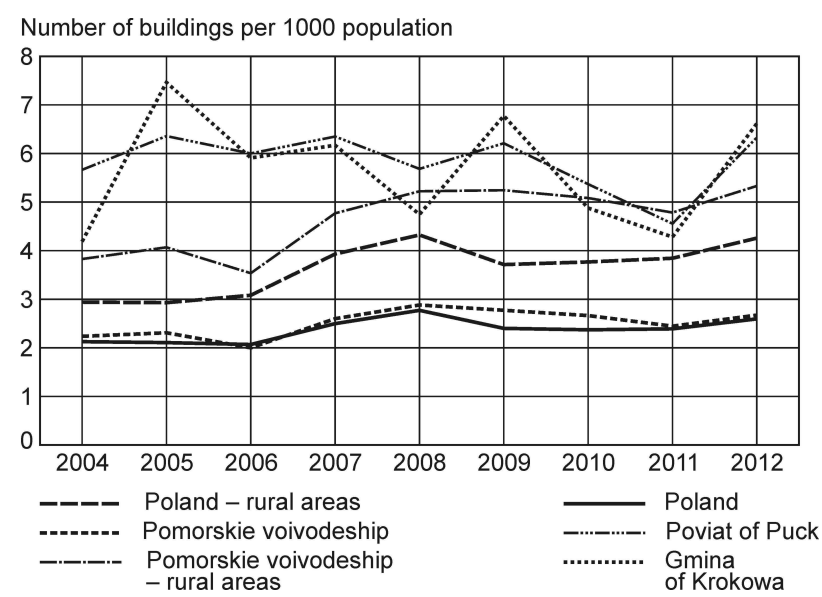

Fig. 8. New buildings put into use per 1000 population in the Gmina of Krokowa against comparable areas Source: compiled by the author on the basis of GUS data

Intense development of settlements which do not possess local development plans contributes to architectural chaos and deepens the lack of spatial order. These effects should be placed on the 'cost side' (negative aspects) of tourism development.

\subsection{ECOLOGICAL AND SOCIAL EFFECTS}

Another negative manifestation of the development of tourism is its environmental cost. In the case of mass tourism such effects as increased noise and pollution (of land - garbage, water - sewage, air - mainly vehicle exhaust) are inevitable. In areas of high natural beauty, forests and dunes are often damaged as a result of tourists leaving hiking trails.

These effects of tourism are also visible in the seaside settlements of the Gmina of Krokowa. The most vulnerable to damage are the attractive areas, which are the main reason for the influx of tourists and the places of their greatest concentration. Frequently observed behaviour includes littering the coastal forest, burying waste and having bonfires on the beach, and climbing dunes. The gmina authorities also 
contribute indirectly to the pollution of the most valuable areas by, for instance, permitting discos on the beach, an inadequate number of toilets and the lack of an adequate supervision of the behaviour of tourists (CHABOWSKA 2013). In efforts to maximise revenue, tourism management in accordance with the principles of sustainable development is extremely difficult, but - due to the desire to preserve the benefits of tourism for the future - absolutely necessary.

Tourism development also leads to some changes in the social environment. On the positive side is an increased sense of satisfaction of most inhabitants with the place where they live (this results in a relatively small emigration). Tourism also encourages the promotion of local culture, in this case Kashubian, by people who care about their language and traditions (MAJEWSKI \& LANE 2001). Tourism development promotes cultural exchange, leading sometimes to conflicts, while these also arise between residents of the areas of tourist reception. These are generally caused by disparities in the distribution of profits from the development of tourism. Excessive tourism causes many difficulties in the daily lives of inhabitants, including lowered quality of services or traffic congestion which intensifies the side effects (such as an increase in the number of road accidents), and even dysfunctional effects (increased crime) (cf. Różycki 2006).

\section{DEVELOPMENT OF THE GMINA OF KROKOWA UNDER THE INFLUENCE OF TOURISM IN THE OPINIONS OF THE INHABITANTS}

The results obtained from questionnaires were influenced by the demographic structure and residence of the respondents. The contribution of income from tourism is greatest in settlements located near the coast, and decreases as we move inland. It is expected that the pattern of responses may vary depending on whether the respondents are also beneficiaries of tourism development or not - especially in financial terms. Therefore, it was assumed that it is appropriate to distribute the questionnaires in a relatively uniform manner in terms of respondents' residence, and cover a variety of ages. The answers were obtained from 276 people: $58 \%$ female and $42 \%$ male. The youngest respondents (18-25 years old) accounted for $23 \%$, those in the following 10-year cohorts (26-35, 36-45 years old etc.), 20, 18, 15 and $13 \%$, respectively, with the oldest $(65+)$ at $11 \%{ }^{5}$. The respondents resided in almost all of the settlements in the gmina, and those from the coastal villages (Dębki, Białogóra, Karwieńskie Błota I and Karwieńskie Błota II) were over-represented two-fold
( $25 \%$ of the total, and $12.2 \%$ of gmina inhabitants). Given the goal of this survey, the questions concerned mainly social, economic and spatial issues.

\subsection{OVERALL ASSESSMENT}

Nearly half of the respondents assess the standard of living in the Gmina of Krokowa as good or very good, $31 \%$ assessed it 'average', and 22\% ticked 'poor' or 'very poor'. It is difficult to comment on this because there is no comparable data. Overall satisfaction was expressed by a little more than two-thirds of the respondents, more than $10 \%$ indicated partial satisfaction (depending on the aspect), and a similar percentage - dissatisfaction (Fig. 9).

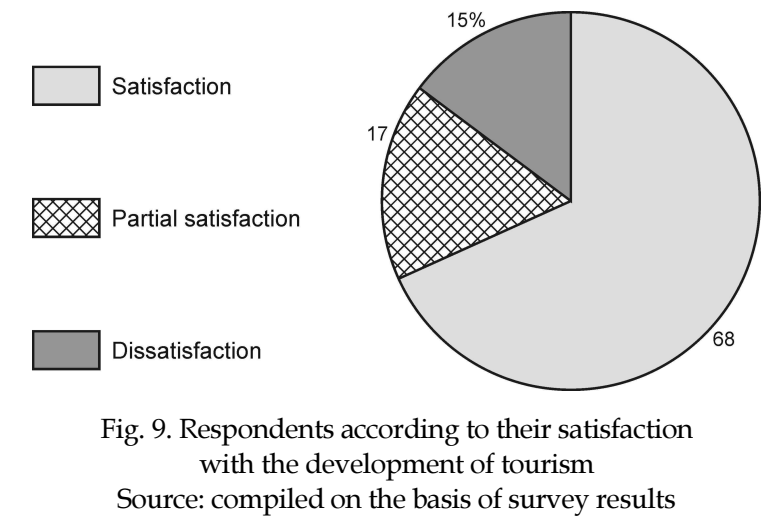

The pattern of answers to the question about the relationship of living standards to the development of tourism was similar: two-thirds claim that the standard of living had improved while in the opinion of $29 \%$ it had not changed, and less than $4 \%$ that it had decreased (Fig. 10).

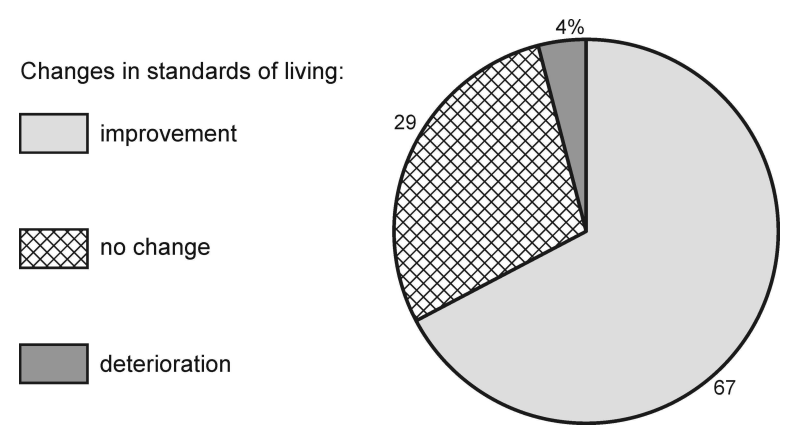

Fig. 10. Assessment of changes in standards of living in the Gmina of Krokowa connected to development Source: compiled on the basis of survey results

Not all settlements equally participate in the benefits. Most respondents (71\%) see a difference in living standards between those who live in coastal areas and the other inhabitants. It is worth noting the 
existence of a certain correlation in the answers to these questions. Subjectivity of evaluation resulting from the possession of sources of income derived from tourism applies to only $26 \%$ (71 respondents). In this group, the majority (39) engage in activities related to accommodation, another 20 work in tourism seasonally, and some are engaged in other kinds of business. The location of the respondents' jobs related to tourism is in line with expectations. Most of them were employed in seaside settlements (Dębki, Białogóra, Karwieńskie Błota) - a total of 52 (i.e. $73 \%$ of those employed in the industry) in addition four worked in neighbouring gminas, and 15 in settlements farther away from the sea (Sławoszyno, Żarnowiec, Odargowo, Minkowice).

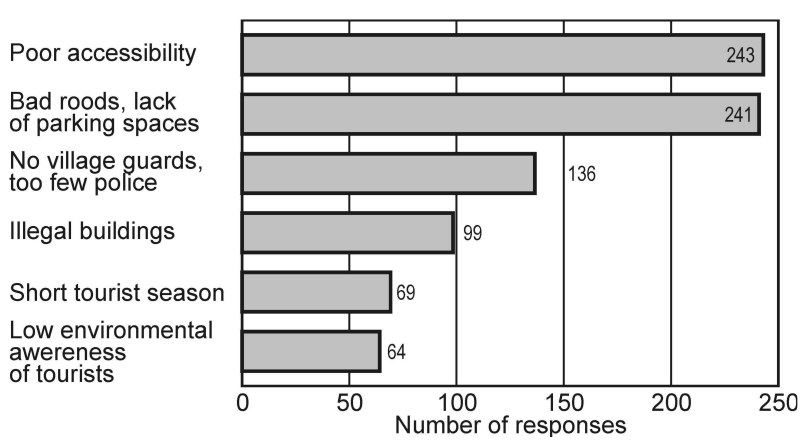

Fig. 11. Disadvantages of the Gmina of Krokowa (according to number of responses)

Source: compiled on the basis of survey results

Interesting answers were provided to the question about the 'disadvantages of the gmina', taking into account both the negative consequences of tourism development and the factors that inhibit or impede its development. The number of responses exceeds the number of respondents due to the possibility of multiple choices (Fig. 11). Almost all agreed that the biggest problem is poor accessibility as well as the poor condition of roads and lack of parking spaces. Quite common is a feeling of a lack of adequate order and security; a feeling of a lack of attention to spatial order (the existence of illegal buildings); as well as the low environmental awareness of tourists. Among the less frequently mentioned problems noteworthy is an indication of a lack of entertainment during bad weather, the low number of recreational facilities and poor cultural offer.

\subsection{SOME DETAILED ASSESSMENTS}

One of the questions (YES/NO) was based on the preparation of the gmina for the increasing number of tourists, and then on the support given for it in their answers. Only $40 \%$ expressed an affirmative opinion. These people often point to the quantitative develop- ment of tourist accommodation (56 responses), the development of the gmina including its infrastructure (16), or the increase in the number of tourist attractions, mainly cultural events (11); some people did not support their opinions with arguments. Figure 12 shows the answers most frequently given to justify a negative opinion.

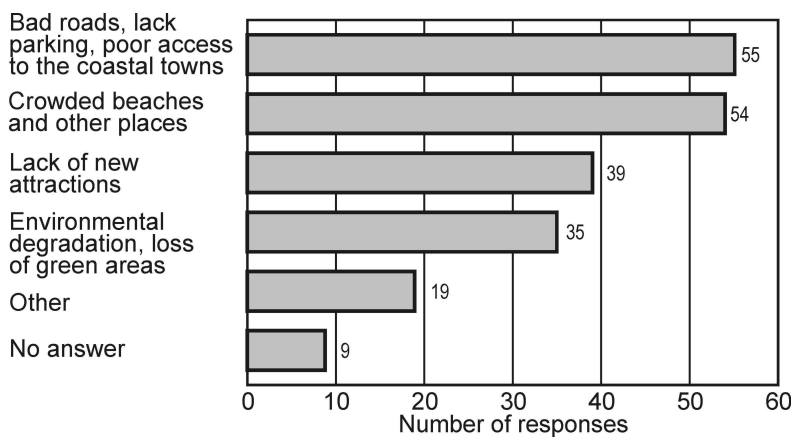

Fig. 12. Justification for the negative assessment of the gmina's preparedness to receive an increasing number of tourists (according to number of responses)

Source: compiled on the basis of survey results

Despite a larger number of negative opinions, the majority of respondents see certain actions taken by residents and gmina authorities as contributing to the attractiveness of the gmina for tourists. Answering an open question they pointed out several such investments and other activities, including the construction of a cycle path (64 respondents) as well as the expansion of accommodation and catering services (47). Fewer pointed to new cultural events, improvements in water and sewage infrastructure and roads, the construction of jetties on Lake Żarnowieckie and the promenade in Dębki, new playgrounds, etc. As many as 35 did not perceive any new investments in the Gmina of Krokowa.

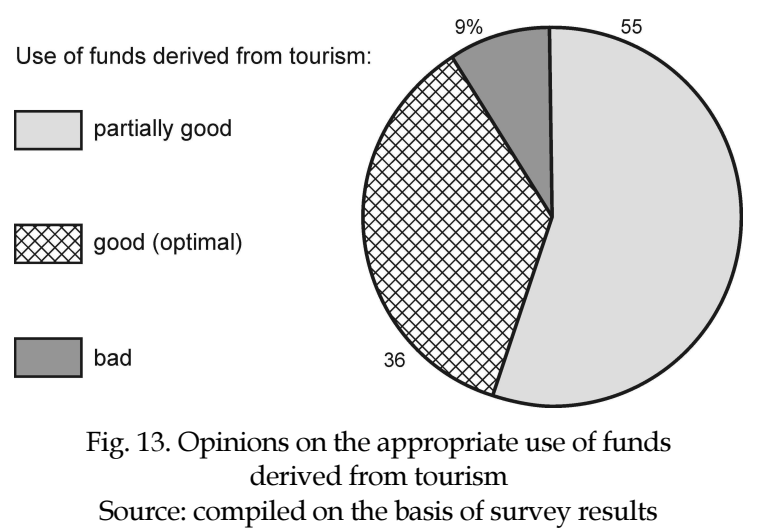

Assessment of the use of funds generated by tourism is also varied. According to $36 \%$ of the respondents (Fig. 13) the Gmina of Krokowa uses this 
revenue well. The majority, however, were of the opinion that besides good investments there are unsuccessful ones.

Ecological (negative) effects of tourism development are commonly observed in the Gmina of Krokowa. Over $90 \%$ of the respondents had witnessed the degradation of the natural environment. Almost all the people in this group had witnessed littering in the forest and the beach, and some of them other forms of nature degradation (Fig. 14).

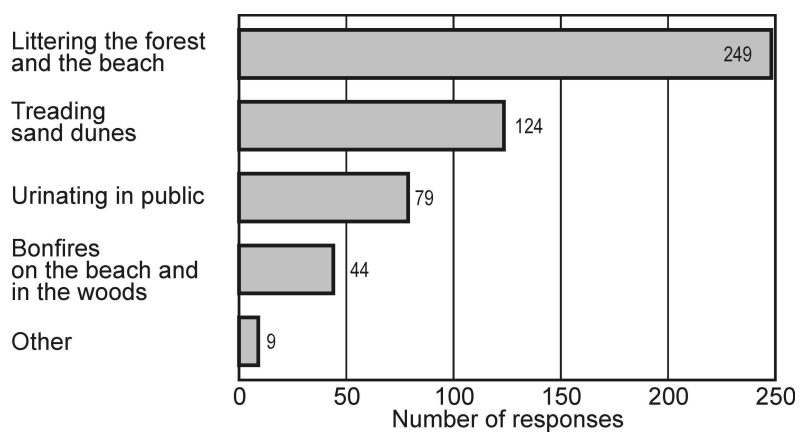

Fig. 14. Types of environmental degradation, as witnessed by the respondents (according to the number of responses)

Source: compiled on the basis of survey results

According to a large group of respondents it is possible to reduce the scale of the negative impact of tourists on the environment through activities such as the establishment of village guards, fining tourists more often, and even placing more rubbish bins and free toilets.

The development of mass tourism mainly oriented to increasing the number of visitors to the Gmina of Krokowa is not currently widely accepted. According to the majority of those interviewed (61\%) tourism should be based on existing land use, and only $13 \%$ supported further intensive development with an expansion of tourism facilities (Fig. 15).

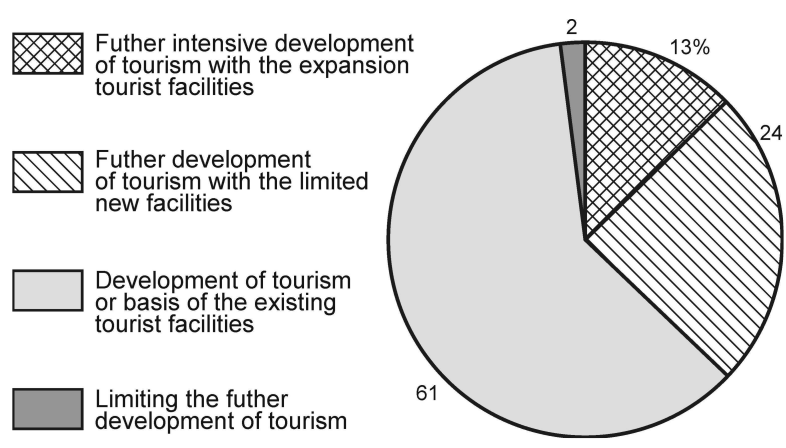

Fig. 15. Preferred directions of further development of tourism in the Gmina of Krokowa

Source: compiled on the basis of survey results

\section{CONCLUSIONS}

One of the gminas with natural beauty and recreational value, promoting the development of tourism, is the Gmina of Krokowa in Pomorskie Voivodeship. In addition to access to the sea with wide, sandy beaches, and Lake Żarnowieckie which allows sailing, the area has valuable natural elements protected in a Coastal Landscape Park and ten nature reserves as well as human tourism sites.

With the increase in tourism - construction, technical infrastructure and tourism facilities are being developed. Currently the number of pensions in the seaside settlements exceeds the number of residential houses (CHABOWSKA 2013). Baretje-Defert's index value for Dębki is 2011, which means that for every one hundred inhabitants there are 2011 beds. Of all the registered businesses $43 \%$ are related to accommodation and catering services aimed at tourists. The importance of tourism is also indicated by the structure of employment and the relatively favourable demographic situation, different than in most villages in Poland. The impact of tourism on the economy is also reflected by relatively high entrepreneurship and low unemployment. The revenues generated by these activities are important for the gmina budget.

The impact of tourism on the economy, finance and infrastructure is definitely positive, and is seen so by most gmina inhabitants. The dominating feeling is satisfaction with the development of tourism in the gmina and the opinion that thanks to tourism standards of life have improved. At the same time more than $70 \%$ of respondents see a difference in the standard of living of the inhabitants of coastal settlements and the rest of the gmina.

The assessment of the impact of tourism in the spatial sphere is less clear. Tourism strongly transforms rural settlements and local authorities do not control the spatial and architectural order, which is particularly felt in coastal settlements. The development of technical infrastructure often does not keep pace with dynamic development, resulting in congestion, car parks and in other public places, as well as environmental degradation. The latter was quite strongly stressed by respondents, which indicates a growing environmental awareness. This, however, cannot be said of a large number of tourists and about some of the entrepreneurs and organisers of mass events (profit above all). The results of the pursuit of profit maximisation are conflicts of interest arising from, besides issues already mentioned, the shrinking of attractive business space. As a result, some businesses are trying to expand into areas previously having other functions. Assessment of the social impact of tourism is also ambiguous. It seems that taking into 
account costs, in terms of severity of adverse events (congestion, accidents, conflicts, crime), the balance is not favourable for the Gmina of Krokowa.

The aim of this study was to investigate the impact of tourism on a coastal gmina in various aspects. The key thesis, concerning the multi-dimensional and significant impact of tourism on the life of the Gmina of Krokowa, has been confirmed both by analysis of statistical data, as well as gmina inhabitants' opinions. The impact of tourism is not only multi-dimensional, but also bi-directional (positive and negative). Trying to balance these effects is not difficult - in the evaluation of gmina residents positive opinions on the effects of tourism predominate, despite full awareness of the costs incurred.

\section{FOOTNOTES}

${ }^{1}$ The article uses the results of questionnaire surveys carried out in 2013 by M. Chabowska as part of her Master's thesis written under the supervision of the author. The same work is also the source of data obtained from the Gmina Krokowa Offices.
2 Excluding towns with 'poviat rights'; total values: $12.1 \%$ and $12.6 \%$

${ }^{3}$ It can be assumed that in reality the drop in unemployment in summer is a bit higher than that recorded in public statistics, due to the fact that some of the temporary employed are not registered.

${ }^{4}$ These figures do not include second houses.

${ }^{5}$ All the survey results have been rounded to the nearest whole percentage

\section{BIBLIOGRAPHY}

CHABOWSKA M., 2013, Rozwój gminy Krokowa pod wptywem funkcji turystycznej, unpublished Master Thesis, Wydział Nauk o Ziemi, UMK, Torun.

CZERWIŃSKI J., 2006, Turystyka. Wybrane zagadnienia, PWSZ, Wałbrzych.

GOŁEMBSKI G., 2002, Metody stymulowania rozwoju turystyki w ujeciu przestrzennym, Akademia Ekonomiczna, Poznań.

MAJEWSKI J., LANE B., 2001, Turystyka wiejska i rozwój lokalny, Fundacja Fundusz Współpracy, Poznań.

RÓŻYCKI P., 2006, Zarys wiedzy o turystyce, Proksenia, Kraków. 